\title{
Career Choice Vis - A - Vis Personality Factors, Parental and Social Influence and Monthly Income of the Family - A Study
}

\author{
Dr. Antara Ghosh ${ }^{1 *}$
}

\section{ABSTRACT}

Students in the modern and fast changing world are trying to choose their career in such a way which would ultimately help them to achieve their success in life. Career choice is a major life decision. Each and every individual is coping with dynamic world and its demands. The present investigation has been designed to study the personality factors and impact of parental and social influence on career choice of the students who want to choose their career as engineer. Accordingly, a group of 120 higher secondary students (under West Bengal Council of Higher Secondary Education) were selected as sample in this investigation. On the other hand, another group of 30 professionals who are engaged in the profession as engineer were also selected as sample in this investigation. Four tools, viz., (a) General Information Schedule (one for the students and the other for professionals), (b) Sixteen Personality Factors [Form-C] Questionnaire (1965), (c) Perceived Impact of Parental Influence Questionnaire and (d) Perceived Impact of Social Influence Questionnaire were used in this investigation. The overall findings reveal that those who want to choose their career as engineer is matched with the professionals. Personality factors take a vital role regarding career choice. The findings also reveal that there seems to be indication of moderate level of parental as well as social influence on career choice. Besides this, monthly income of the family and gender difference also have significant role in connection with career choice. Adequate measures may be taken by parents, teachers, counselors and other wellwishers who are able to help the students to choose a particular career for their future development.

Keywords: Career, Personality Factors, Parental, Social Influence, Monthly Income, Family.

During the twilight zone of his infancy a man learns to enjoy the presence of others and to achieve his goals with others' help and cooperation. These goals may be physical comforts, protection, survival etc. Different streams from the spectrum of knowledge - self-knowledge, knowledge from others and knowledge of the environment - all initiated and crystallized in this sacred place of him. A career is traditionally seen as a course of successive situation that make

\footnotetext{
${ }^{1}$ Guest Lecturer at Bangabasi College, Calcutta University

*Responding Author

(c) 2016 I A Ghosh; licensee IJIP. This is an Open Access Research distributed under the terms of the Creative Commons Attribution License (http://creativecommons.org/licenses/by/2.0), which permits unrestricted use, distribution, and reproduction in any Medium, provided the original work is properly cited.
} 


\section{Career Choice Vis - A - Vis Personality Factors, Parental and Social Influence and Monthly Income of the Family - A Study}

up a person's work life. Students in the modern and fast changing world are trying to seek for those careers which would ultimately led them to achieve fairly in life. Career choice is a major life decision. Career choice influence the way an individual feel about him/her, their life-style, the kind of colleagues, types of work environment and social relationship one will have. In the present scenario of competitive world everyone want to build up a solid and prosperous career which not only bring them handsome salary but also establish them in society as a worthy person, enhance their self-esteem. However, the choice of career by an individual is influenced by various factors and among them parental influence is very important. Students sometimes suffer from dilemma for choosing a particular career for their future development. In the present day scenario, not only students but also their parents are anxious and aware about the career choice of their children. Parents believe that right selection of career brings happiness and success in life. They always try to provide the requirement of their children as far as possible in spite of their limited resources. The relationship between specific parental behavior and career development of young adolescents was assessed by Keller and Whiston (2008).The findings reveal that parental behaviors tended to relate more to career decision making self-efficacy than to career maturity and also general psychosocial parenting behaviors appeared to be more salient than career focused parent behaviors. Lease et al. (2009) investigated the relations between the maternal/paternal attachment, parenting styles, locus of control, career decision self-efficacy and gender differences. Data analysis using hierarchical multiple regression revealed that attachment was relevant for females' career decision self-efficacy but not for men's. Authoritarian parenting styles were predictive of women's career decision self-efficacy. Another finding reveals that the role of parents in youth career development is generally acknowledged though, often, perfunctorily. This inquiry examines youth perceptions of parental influence on their career development. One can ask young men and women about specific career development attitudes and behaviors that bear on their relations with their parents. The results confirm the trend of recent studies that report compatibility between parent and youth values, aspirations, and plans. Of all the people to whom youth can turn for help with making career plans, most look to their mothers. The findings apply across gender, to young men as well as young women; and they apply across race, to minority youth as well as majority-culture youth. The results underscore the importance of parents as allies and resources for career counselors in facilitating youth career development (Otto, 2000).

All of our career choices take place within the context of society and the economy. Events that take place in our lives may affect the choices available to us and even dictate our choices to a certain degree. Changes in the economy and resulting job market may also affect how our careers develop. Savickaset al. (2002) suggests that planful competence in career development related to greater realization of one's potential and a higher degree of social adjustment. The study of Smith and Betz (2000) investigated the involved development and psychometric evaluation of the Scale Perceived Social Self-Efficacy (PSSE), a measure of self-efficacy expectations with 


\section{Career Choice Vis - A - Vis Personality Factors, Parental and Social Influence and Monthly Income of the Family - A Study}

respect to a range of social behaviors. Social self-efficacy was also strongly related to shyness, which has been found to seriously hinder career development processes in young adults.

In time of career choice one cannot ignore a person's interest, aptitude, and motivation and also parental and social influences on career choice. Besides this, personality is also an important factor in this regard. It helps a person to organize and make sense of one's experience, preferences and interests. There is a distinct effect if someone chooses a career which is not congruent with his personality. A particular job makes differing demands on people and that people differ in the abilities they possess. Future job performance therefore, is enhanced when there is a high ability - job fit. If someone who is introvert (or shy) chooses a job of sales executive or salesmanship could not do well and exceed the expectation of others. The effects of personality and career decision making self-efficacy on progress in career choice commitment was investigated by Wang et al. (2006).The findings revealed that for white students, selfefficacy fully mediated the relationship between extraversion and career choice commitment, whereas for students of color, in which neuroticism and extraversion were related to career choice commitment directly and indirectly through self-efficacy. Duffy et al. (2009) examined relationships among the variables in a sample of 282 medical students (169 women, 113 men) who responded to the Strong Interest Inventory, NEO Personality Inventory-Revised, and the Physical values in Practice Scale. The results indicated significant relationships between openness and artistic interests and between extraversion and enterprising interests, social interests, and management work values. Another study conducted by Lievenset al. (2002) investigated (1) which personality traits are typical of medical students as compared to other students, and (2) which personality traits predict medical student performance in pre-clinical years. In this study the higher scores for extraversion and agreeableness, two dimensions defining the interpersonal dynamic, may be beneficial for engineer's collaboration and communication skills in future professional because conscientiousness affects examination results and can be reliably assessed at the start of a medical study career. Personality assessment may be a useful tool in students counseling and guidance. A study was conducted by Hojatet al. (1999) who designed to compare male and female medical students on selected personality attributes that could influence their academic attainment and personal success. Men scored significantly higher on the intensity of loneliness, and women scored higher on general anxiety, test anxiety and neuroticism scales, but the magnitudes of the effect size estimates were not large. No significant gender difference was observed on measures of chronicity of loneliness, depression, extraversion, self-esteem, external locus of control, perception of general health and perceptions of the mother and the father. Women who experienced stressful life events, such as death in the family or personal illness, appraised these events more negatively than did their male counterparts.

Socio economic status plays an important role in the life of a person. The status opens the ways for his progress. Intelligence, attitudes, aptitudes and even interests are patterned by socio 


\section{Career Choice Vis - A - Vis Personality Factors, Parental and Social Influence and Monthly Income of the Family - A Study}

economic background of the individual. The socio economic status pays rewards and punishment both to a person. Chaudhari et al.(1998). Socio economic status refers to the position that an individual and family occupies with reference to prevailing average standards, cultural possession and participation in group activity of community. It is also said that socio economic status includes both the social and economic status of the individual in the group. The variations in achievement are also due to the differences in socio economic status of the children, differential treatment given by parents, parent's educational level, and influence of the surroundings and so on. The influence of socio-cultural factors on various aspects of individual's development has particularly caught the attention of educationists. Individual success and failure can also be judged by facilities and environment provided for his study, self-concept and study habits. As pointed out by Sawrey and Telford (1964) children belonging to higher socio economic status are not only brilliant but also are provided better opportunities for developing intellectually, physically and emotionally. The type of intellectual environment in the home will definitely have an impact on the school achievement of the child and this intellectual environment in turn is determined by intellectual level of parents, parent's education, occupation, income, size of the family etc. The purpose of career assessment is to gather the relevant information for assisting clients in career choice and decision-making. Socio-cultural realities and their psychological concomitants are the significant factors to assess it.

Career construction offers a developmental theory of vocational behavior and a career assessment and counseling model counselor can use to promote client's subjective wellbeing. Career construction assist individuals with using work to foster self-completion and derive meaning, satisfaction and happiness as they design their lives. Career construction counseling promotes subjective well-being because its aims are consistent with increasing both immediate life satisfaction and overall life contentment (Hartung and Taber, 2008). On the other hand, Perry et al.(2010) drawing from the contributions of vocational psychology, examined school engagement as a mediator of academic performance through the effects of career preparation (career planning, career decision-making self-efficacy), parental career support, and teacher support among diverse urban youth in middle school and high school. Based on structural equation modeling, all structural paths of the proposed hypothetical model were significant. The effects of teacher support and parental career support on school engagement were mediated by career preparation; in turn, the effect of career preparation on grades was mediated by school engagement. Teacher support also had a direct effect on school engagement. The middle school students had significantly higher grades than the high school students, but there were no significant grade-level differences in terms of school engagement, career preparation, parental career support, or teacher support. The reason for choosing a particular career may provide satisfaction in their future life and personality factor may take an important role in this regard. 
Considering the above, the present investigation has been designed to study the career choice in connection with personality factors, parental and social influence and monthly income of the family as opined by the students who want to choose their career as engineer.

\section{OBJECTIVES:}

1. To study the personality factors of the students who want to choose their career as engineer.

2. To study whether personality factors of the students who want to choose their career as engineer match or do not match in connection with the personality factors of the professionals who are engaged in the profession as engineer.

3. To study whether there is any impact of parental and social influence on career choice in connection with the gender difference or not.

4. To study whether there is any impact of parental as well as social influence on career choice in connection with the monthly income of the family or not.

\section{Hypotheses:}

Hypothesis-I: Personality factors of the students who want to choose their career as engineer is matched with the personality factors of the professionals who are engaged in the profession as engineer.

Hypothesis-IIA: Parental influence on career choice as engineer is differentially associated with gender difference.

Hypothesis-IIB: Social influence on career choice as engineer is differentially associated with gender difference.

Hypothesis-IIIA: Parental influence on career choice as engineer differs significantly with monthly income of the family.

Hypothesis-IIIB: Social influence on career choice as engineer differs significantly with monthly income of the family.

\section{METHODS:}

\section{Study Area And Sample}

A group of 120 students of class XI and XII belonging to Kolkata city, India who wants to choose their career as engineer in future were selected as sample in this investigation. The pertinent characteristics of the students are as follows-

- $\quad$ Age: 16 to 18 years.

- Gender: Equal gender ratio.

- Monthly income of the family:

$>\quad$ Group - A: Rs. $20,001 /$ - to Rs. 30,000/-
$>\quad$ Group - B: Rs. 30,001/- to Rs. 40,000/- 
The students are from West Bengal Council of Higher Secondary Education (Both Bengali and English method of instructions).

Table -A: Distribution of sample (students) who want to choose their career as engineer and Engineer.

\begin{tabular}{|l|l|l|l|}
\hline \multirow{2}{*}{ Monthly income of the family } & \multicolumn{2}{|c|}{ Engineer } & \multirow{2}{*}{ Total } \\
\cline { 2 - 4 } & Boys & Girls & 60 \\
\hline Rs.20,001/- to Rs.30,000/- & 30 & 30 & 60 \\
\hline $\begin{array}{l}\text { Rs.30,001/- } \\
\text { to } \\
\text { Rs.40,000/- }\end{array}$ & 30 & 30 & \\
\hline Total & 60 & 60 & $\mathbf{1 2 0}$ \\
\hline
\end{tabular}

Another group of 30 professionals, viz. engineer who are engaged in their profession for at least 10 years were selected as sample in this investigation mainly to know the personality factors by applying "Sixteen Personality Factor" (Form-C) questionnaire.

\section{Tools Used}

General Information Schedule (for Students): It consists of items like name, address, age, gender, class, family type, presence of siblings, father's occupation, mother's occupation and monthly income of the family.

General Information Schedule (for Professionals): It consists of items like name, address, age, gender, family type and durations of service.

Sixteen Personality Factor (16P.F.) Questionnaires (Form-C): This test is developed by Raymond B. Cattell (1965), is a factor - analytically derived questionnaire for personality assessment. In this questionnaire raw score for each of the 16 personality factors is obtained through aweighted procedure where particular responses count as " 1 " or " 0 " or "2" except the factor ' $\mathrm{B}$ ' where particular responses count as " 0 " or " 1 " summative towards the raw score. The sum scores are then compared to the desired normative score table in the tabular supplement standard ten (sten) score. This sten score is entered on the profile form and subsequently final calculations were done.

Perceived Impact of Parental Influence Questionnaire: It consists of 20 statements, answerable in a 5 - point scale from "Strongly agree" to "strongly disagree" where "High score indicates maximum parental influence on career choice” and vice-versa as expressed by the students who want to choose their career as engineer in the near future. Odd-even split -half reliability is 0.80 .

Perceived Impact of Social Influence Questionnaire: It consists of 20 statements, answerable in a 5 - point scale from "Strongly agree" to "strongly disagree" where "High score indicates maximum social influence on career choice" and vice-versa as expressed by the students who want to choose their career as engineer in the near future. Odd-even split -half reliability is 0.78 . 
Career Choice Vis - A - Vis Personality Factors, Parental and Social Influence and Monthly Income of the Family - A Study

\section{Administration, Scoring And Statistical Treatment:}

General Information Schedule, Sixteen Personality Factors (16 P.F.) Questionnaire (Form - C) and Perceived Impact of Parental Influence Questionnaire were administered to a group of selected sample by giving proper instruction. Data were collected and properly scrutinized. Scoring was done with the help of scoring key. In order to determine the different characteristic features, frequency and percentages were calculated. Both qualitative and quantitative analyses were done. Comparisons were made by applying " $t$ "- test.

\section{RESULT AND INTERPRETATION}

General Characteristics Data of the student inserted in Table 1 reveals the characteristic features of the students under study.

Table-1: General Information of the students who want to choose their career as engineer

\begin{tabular}{|c|c|c|c|c|c|c|}
\hline \multirow[t]{2}{*}{$\begin{array}{ll}\text { General } & \text { Characteristics } \\
\text { Features } & \end{array}$} & \multicolumn{2}{|c|}{$\begin{array}{l}\text { BOYS } \\
(\mathrm{N}=60)\end{array}$} & \multicolumn{2}{|c|}{$\begin{array}{l}\text { GIRLS } \\
(\mathrm{N}=60)\end{array}$} & \multicolumn{2}{|c|}{$\begin{array}{l}\text { COMBINED } \\
(\mathrm{N}=120)\end{array}$} \\
\hline & f & $\%$ & $\mathbf{f}$ & $\%$ & $\mathbf{f}$ & $\%$ \\
\hline 1)Age (Mode Value) & \multicolumn{2}{|c|}{18 years } & \multicolumn{2}{|c|}{17 years } & \multicolumn{2}{|c|}{17.5 years } \\
\hline $\begin{array}{l}\text { 2)Class } \\
\text { a)Class-XI } \\
\text { b)Class-XII }\end{array}$ & $\begin{array}{l}24 \\
36\end{array}$ & $\begin{array}{l}40 \\
60\end{array}$ & $\begin{array}{l}28 \\
32\end{array}$ & $\begin{array}{l}46.67 \\
53.33\end{array}$ & $\begin{array}{l}52 \\
68\end{array}$ & $\begin{array}{l}43.33 \\
56.67\end{array}$ \\
\hline $\begin{array}{l}\text { 3)Father's occupation } \\
\text { a)Business } \\
\text { b)Service }\end{array}$ & $\begin{array}{l}26 \\
34\end{array}$ & $\begin{array}{l}43.33 \\
56.67\end{array}$ & $\begin{array}{l}15 \\
45\end{array}$ & $\begin{array}{l}25.00 \\
75.00\end{array}$ & $\begin{array}{l}41 \\
79\end{array}$ & $\begin{array}{l}34.17 \\
65.83\end{array}$ \\
\hline $\begin{array}{l}\text { 4)Mother's occupation } \\
\text { a)Housewife } \\
\text { b)Business } \\
\text { c)Service }\end{array}$ & $\begin{array}{l}35 \\
00 \\
25\end{array}$ & $\begin{array}{l}58.33 \\
00.00 \\
41.67\end{array}$ & $\begin{array}{l}37 \\
00 \\
23\end{array}$ & $\begin{array}{l}61.67 \\
00.00 \\
38.33\end{array}$ & $\begin{array}{l}72 \\
00 \\
48\end{array}$ & $\begin{array}{l}60.00 \\
00.00 \\
40.00\end{array}$ \\
\hline
\end{tabular}

The General characteristics data inserted in Table 2 explicitly depicted the characteristics features of the professionals who are engaged in the profession as engineer in terms of their age, gender and duration of services.

Table-2: General Information of the subjects who are engaged in the profession as engineer

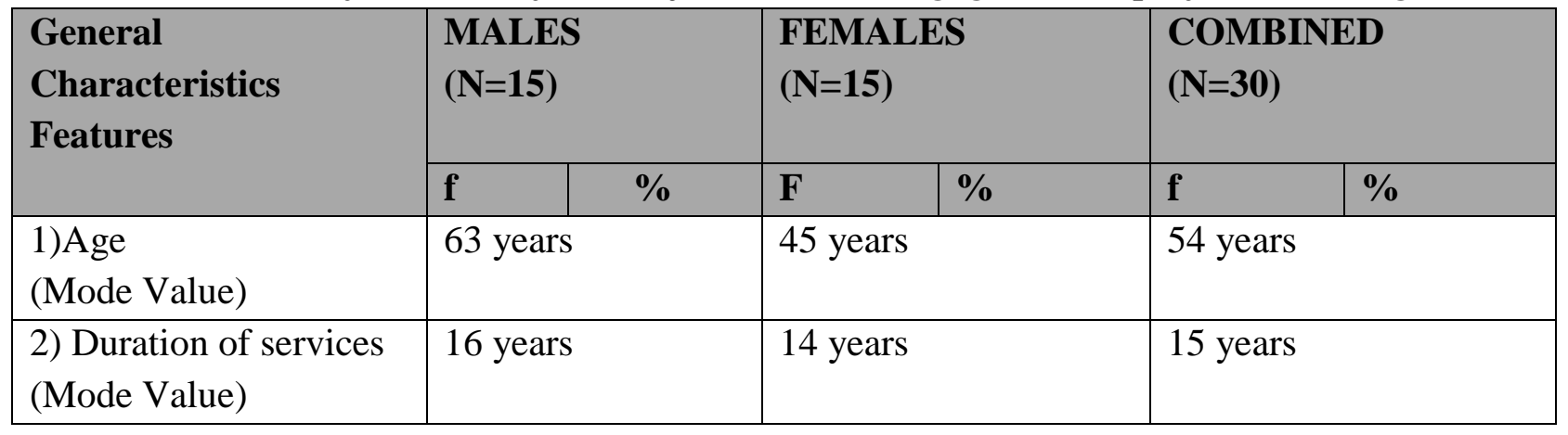


Data inserted in Table-3A, 3B and 3C reveal that the personality factors of the students who want to choose their career as engineer in the near future and also who are engaged in the profession as engineer. Overall findings reveal that those who want to choose their career as engineer are warm and outgoing, conscientious, trustful and self-sufficient. On the other hand, those who are engaged in the professions as engineer are warm and outgoing, mature, conscientious, trustful, confident, self-sufficient and self-controlled. Except factor $\mathrm{H}$ (timid), there is a similarity between these two groups in connection with the personality factors as revealed by applying Sixteen Personality Factors (16 P.F.) test. So, it can be said that those who want to choose their career as engineer is matched with the personality factors of the professionals who are engaged in the profession as engineer. Analysis of data further reveals that high score in Factor C (mature) and Factor Q3 (selfcontrolled) indicate that those who are engaged in the profession as engineers are experienced subjects. Lievenset al. (2002) investigated (1) which personality traits are typical of medical students as compared to other students and (2) which personality traits predict medical student performance in pre-clinical years. In this study the higher scores for extraversion and agreeableness, may be beneficial for engineer's collaboration and communication skills in future professional because conscientiousness affects examination results and can be reliably assessed at the start of a medical study career. Thus, the Hypothesis-I, which postulates "Personality factors of the students who want to choose their career as engineer is matched with the personality factors of the professionals who are engaged in the profession as engineer" - is accepted in this investigation.

Table-3A: Personality factors of the students who want to choose their career as engineer

\begin{tabular}{|c|c|c|c|c|c|c|c|c|c|}
\hline \multirow{3}{*}{$\begin{array}{l}\text { Personality } \\
\text { factors } \\
\text { P.F.) }\end{array}$} & \multicolumn{9}{|c|}{ Want to choose the profession as engineer } \\
\hline & \multicolumn{3}{|c|}{ BOYS } & \multicolumn{3}{|c|}{ GIRLS } & \multicolumn{3}{|c|}{ COMBINED } \\
\hline & $\mathbf{N}$ & Mean & S.D & $\mathbf{N}$ & Mean & S.D & $\mathbf{N}$ & Mean & S.D \\
\hline A & 60 & 8.82 & 2.30 & 60 & 6.17 & 1.53 & 120 & 7.49 & 1.91 \\
\hline $\mathbf{B}$ & 60 & 5.59 & 1.84 & 60 & 5.28 & 1.94 & 120 & 5.43 & 1.89 \\
\hline $\mathbf{C}$ & 60 & 5.89 & 1.90 & 60 & 5.74 & 2.18 & 120 & 5.81 & 2.04 \\
\hline $\mathbf{E}$ & 60 & 5.28 & 1.89 & 60 & 5.00 & 2.24 & 120 & 5.14 & 2.06 \\
\hline $\mathbf{F}$ & 60 & 5.78 & 2.07 & 60 & 5.84 & 2.01 & 120 & 5.81 & 2.04 \\
\hline $\mathbf{G}$ & 60 & 7.26 & 2.98 & 60 & 7.56 & 2.11 & 120 & 7.41 & 2.54 \\
\hline $\mathbf{H}$ & 60 & 4.25 & 1.58 & 60 & 2.61 & 1.91 & 120 & 3.43 & 1.74 \\
\hline I & 60 & 5.17 & 1.62 & 60 & 5.23 & 1.88 & 120 & 5.20 & 1.75 \\
\hline $\mathbf{L}$ & 60 & 3.85 & 1.50 & 60 & 4.11 & 1.03 & 120 & 3.98 & 1.26 \\
\hline $\mathbf{M}$ & 60 & 5.19 & 2.18 & 60 & 6.44 & 1.96 & 120 & 5.81 & 2.01 \\
\hline $\mathbf{N}$ & 60 & 5.01 & 2.04 & 60 & 5.23 & 1.52 & 120 & 5.12 & 1.78 \\
\hline $\mathbf{0}$ & 60 & 4.86 & 1.99 & 60 & 5.19 & 2.05 & 120 & 5.02 & 2.02 \\
\hline Q1 & 60 & 5.80 & 1.94 & 60 & 6.10 & 1.85 & 120 & 5.95 & 1.89 \\
\hline Q2 & 60 & 7.90 & 2.53 & 60 & 7.53 & 2.65 & 120 & 7.71 & 2.59 \\
\hline Q3 & 60 & 6.13 & 1.70 & 60 & 5.26 & 1.05 & 120 & 5.69 & 1.37 \\
\hline Q4 & 60 & 5.10 & 2.00 & 60 & 6.20 & 1.93 & 120 & 5.65 & 1.96 \\
\hline
\end{tabular}


Career Choice Vis - A - Vis Personality Factors, Parental and Social Influence and Monthly Income of the Family - A Study

Table-3B: Personality factors of the subjects who are engaged in the profession as engineer

\begin{tabular}{|c|c|c|c|c|c|c|c|c|c|}
\hline \multirow{3}{*}{$\begin{array}{l}\text { Personality factors } \\
\text { (16 P.F.) }\end{array}$} & \multicolumn{9}{|c|}{ Engaged in the profession as engineer } \\
\hline & \multicolumn{3}{|c|}{ MALES } & \multicolumn{3}{|c|}{ FEMALES } & \multicolumn{3}{|c|}{ COMBINED } \\
\hline & $\mathbf{N}$ & Mean & S.D & $\mathbf{N}$ & Mean & S.D & $\mathbf{N}$ & Mean & S.D \\
\hline $\mathbf{A}$ & 15 & 7.96 & 1.59 & 15 & 6.15 & 1.08 & 30 & 7.05 & 1.33 \\
\hline $\mathbf{B}$ & 15 & 5.93 & 1.72 & 15 & 6.03 & 2.06 & 30 & 5.98 & 1.89 \\
\hline $\mathbf{C}$ & 15 & 8.02 & 2.01 & 15 & 6.27 & 1.59 & 30 & 7.17 & 1.80 \\
\hline $\mathbf{E}$ & 15 & 5.63 & 1.94 & 15 & 5.33 & 1.44 & 30 & 5.48 & 1.69 \\
\hline $\mathbf{F}$ & 15 & 7.01 & 2.53 & 15 & 5.06 & 2.16 & 30 & 6.03 & 2.34 \\
\hline $\mathbf{G}$ & 15 & 7.43 & 1.75 & 15 & 7.47 & 1.63 & 30 & 7.45 & 5.41 \\
\hline $\mathbf{H}$ & 15 & 5.27 & 2.02 & 15 & 5.73 & 1.99 & 30 & 5.50 & 2.01 \\
\hline I & 15 & 5.17 & 1.62 & 15 & 6.11 & 1.83 & 30 & 5.64 & 1.72 \\
\hline $\mathbf{L}$ & 15 & 4.85 & 2.20 & 15 & 4.76 & 2.09 & 30 & 4.80 & 2.14 \\
\hline $\mathbf{M}$ & 15 & 5.80 & 1.94 & 15 & 5.95 & 1.89 & 30 & 5.87 & 1.91 \\
\hline $\mathbf{N}$ & 15 & 5.77 & 2.12 & 15 & 5.30 & 1.46 & 30 & 5.53 & 1.79 \\
\hline $\mathbf{O}$ & 15 & 3.75 & 2.15 & 15 & 5.07 & 1.89 & 30 & 4.41 & 2.02 \\
\hline Q1 & 15 & 6.11 & 1.59 & 15 & 5.16 & 1.75 & 30 & 5.63 & 1.67 \\
\hline Q2 & 15 & 7.25 & 2.36 & 15 & 8.22 & 2.98 & 30 & 7.73 & 2.67 \\
\hline Q3 & 15 & 7.59 & 3.52 & 15 & 7.89 & 1.92 & 30 & 7.74 & 2.72 \\
\hline Q4 & 15 & 5.92 & 1.52 & 15 & 6.19 & 2.17 & 30 & 6.05 & 1.84 \\
\hline
\end{tabular}

Table-3 C: Analysis regarding the personality factors of the subjects who are engaged in the profession as engineer and who want to choose their career as engineer

\begin{tabular}{|l|l|l|l|l|l|l|l|}
\hline $\begin{array}{l}\text { Engaged } \\
\text { (at least 10 years of experience) }\end{array}$ \\
$\begin{array}{l}\text { Persona } \\
\text { lity } \\
\text { factors }\end{array}$ & MALE & FEMALE & $\begin{array}{l}\text { COMBIN } \\
\text { ED }\end{array}$ & $\begin{array}{l}\text { Persona } \\
\text { lity } \\
\text { factors }\end{array}$ & BOYS & GIRLS & $\begin{array}{l}\text { COMBIN } \\
\text { ED }\end{array}$ \\
\hline A & $\begin{array}{l}\text { Warm, } \\
\text { outgoing }\end{array}$ & Average & $\begin{array}{l}\text { Warm, } \\
\text { outgoing }\end{array}$ & A & $\begin{array}{l}\text { Warm, } \\
\text { outgoing }\end{array}$ & Average & $\begin{array}{l}\text { Warm, } \\
\text { outgoing }\end{array}$ \\
\hline B & Average & Average & Average & B & Average & Average & Average \\
\hline C & Mature & Average & Mature & C & Average & Average & Average \\
\hline E & Average & Average & Average & E & Average & Average & Average \\
\hline F & $\begin{array}{l}\text { Enthusiast } \\
\text { ic }\end{array}$ & Average & Average & F & Average & Average & Average \\
\hline G & $\begin{array}{l}\text { Conscienti } \\
\text { ous }\end{array}$ & $\begin{array}{l}\text { Conscienti } \\
\text { ous }\end{array}$ & $\begin{array}{l}\text { Conscienti } \\
\text { ous }\end{array}$ & G & $\begin{array}{l}\text { Conscienti } \\
\text { ous }\end{array}$ & $\begin{array}{l}\text { Conscienti } \\
\text { ous }\end{array}$ & $\begin{array}{l}\text { Conscienti } \\
\text { ous }\end{array}$ \\
\hline H & Average & Average & Average & H & Timid & Timid & Timid \\
\hline I & Average & Average & Average & I & Average & Average & Average \\
\hline L & Trustful & Trustful & Trustful & L & Trustful & Trustful & Trustful \\
\hline M & Average & Average & Average & M & Average & Average & Average \\
\hline
\end{tabular}


Career Choice Vis - A - Vis Personality Factors, Parental and Social Influence and Monthly Income of the Family - A Study

\begin{tabular}{|l|l|l|l|c|l|l|l|}
\hline N & Average & Average & Average & $\mathbf{N}$ & Average & Average & Average \\
\hline O & Confident & Average & Confident & O & Confident & Average & Average \\
\hline Q1 & Average & Average & Average & Q1 & Average & Average & Average \\
\hline Q2 & $\begin{array}{l}\text { Self - } \\
\text { sufficient }\end{array}$ & $\begin{array}{l}\text { Self - } \\
\text { sufficient }\end{array}$ & $\begin{array}{l}\text { Self - } \\
\text { sufficient }\end{array}$ & Q2 & $\begin{array}{l}\text { Self - } \\
\text { sufficient }\end{array}$ & $\begin{array}{l}\text { Self } \\
\text { sufficient }\end{array}$ & $\begin{array}{l}\text { Self } \\
\text { sufficient }\end{array}$ \\
\hline Q3 & $\begin{array}{l}\text { Self - } \\
\text { controlled }\end{array}$ & $\begin{array}{l}\text { Self - } \\
\text { controlled }\end{array}$ & $\begin{array}{l}\text { Self - } \\
\text { controlled }\end{array}$ & $\mathbf{Q 3}$ & Average & Average & Average \\
\hline Q4 & Average & Average & Average & Q4 & Average & Average & Average \\
\hline
\end{tabular}

Data inserted in Table-4A reveals the comparative picture of parental influence upon the boys and girls in connection with career choice. It can be said from the findings that parental influence is more upon the girls than upon the boys. Analysis of data reveals no significant difference was observed for two groups. Thus, the Hypothesis-IIA which postulates, "Parental influence on career choice as engineer is differentially associated with gender difference" - is rejected for all comparisons. Similarly, data inserted in Table-4B reveals the comparative picture of the social influence on career choice upon the boys and girls. No significant difference was observed in the comparisons. Thus, the Hypothesis-IIB which postulates, "Social influence on career choice as engineer is differentially associated with gender difference"-is rejected in this investigation.

Table-4A: Comparison between the boys and girls in terms of parental influence on career choice as engineer

\begin{tabular}{|c|c|c|c|c|c|c|c|}
\hline \multirow{3}{*}{$\begin{array}{l}\text { Monthly income of } \\
\text { the family (category } \\
\text { - wise) }\end{array}$} & \multicolumn{6}{|c|}{ Parental influence } & \multirow{3}{*}{ 't'-value } \\
\hline & \multicolumn{3}{|c|}{ BOYS } & \multicolumn{3}{|c|}{ GIRLS } & \\
\hline & $\mathbf{N}$ & Mean & S.D & $\mathbf{N}$ & Mean & S.D & \\
\hline Group-A & 30 & 61.23 & 09.86 & 30 & 64.43 & 09.11 & $1.31 *$ \\
\hline Group-B & 30 & 68.93 & 09.77 & 30 & 67.37 & 10.51 & $0.59 *$ \\
\hline
\end{tabular}

Score range: 20 to 100

High score indicates maximum parental influence on career choice and vice-versa.

* Difference is insignificant, $* * \mathrm{p}<0.05$

Table-4 B: Comparison between boys and girls the in terms of social influence on Career choice as engineer

\begin{tabular}{|c|c|c|c|c|c|c|c|}
\hline \multirow{3}{*}{$\begin{array}{l}\text { Monthly income } \\
\text { of the family } \\
\text { (Category - wise) }\end{array}$} & \multicolumn{6}{|c|}{ Social influence } & \multirow{3}{*}{ 't'-value } \\
\hline & \multicolumn{3}{|c|}{ BOYS } & \multicolumn{3}{|c|}{ GIRLS } & \\
\hline & $\mathbf{N}$ & Mean & S.D & $\mathbf{N}$ & Mean & S.D & \\
\hline Group-A & 30 & 56.27 & 11.78 & 30 & 58.87 & 10.63 & $0.57 *$ \\
\hline Group -B & 30 & 57.47 & 09.78 & 30 & 59.53 & 08.94 & $0.85 *$ \\
\hline
\end{tabular}

Score range: 20 to 100

High score indicates maximum social influence on career choice and vice-versa.

* Difference is insignificant.

Group-A: Rs. 20,001/- to Rs. 30,000/-

Droup-B: Rs. 30,001/- to Rs. 40,000/-

(c) The International Journal of Indian Psychology, ISSN 2348-5396 (e)| ISSN: 2349-3429 (p) | 164 
Data inserted in Table-5A reveals the parental influence upon the students who belongs to families of different monthly income. It can be said from the findings that parental influence is more upon those who belong to group-B category. This is true for boys and girls also. The reasons behind this are mainly to get high profile as well as prestigious job, priority in connection with the parents and proper identity in the society. When comparison was made (only for boys) in terms of parental influence, significant difference was observed between group A vs. group B. Keller and Whiston (2008) revealed that parental behavior tended to relate more to career decision making self-efficacy than to career maturity and also general psychosocial parenting behaviour appeared to be more salient than career focused parent behaviour. On the other hand, for girls, no significant difference was observed in connection with group- wise comparisons. Thus, the Hypothesis-IIIA, which postulates, "Parental influence on career choice as engineer differs significantly with monthly income of the family"- is accepted only for group-A vs. group- B (boys) and is rejected for all other comparisons. Similarly, data inserted in Table-5B reveals the moderate level of social influence regarding career choice as engineer. When comparison was made between the groups separately, no significant difference was observed in all the comparisons. Thus, the HypothesisIIIB, which postulates, "Social influence on career choice as engineer differs significantly with monthly income of the family"- is rejected for all comparisons.

Table-5A: Comparison between the groups (considering monthly income of the family) in terms of parental influence on career choice as engineer

\begin{tabular}{|c|c|c|c|c|c|c|c|c|}
\hline \multirow{2}{*}{$\begin{array}{l}\text { Comparison } \\
\text { between the } \\
\text { monthly } \\
\text { income of the } \\
\text { family } \\
\text { (category - } \\
\text { wise) }\end{array}$} & \multicolumn{3}{|c|}{ Parental influence (BOYS) } & \multirow[b]{2}{*}{$\begin{array}{l}\text { 't'- } \\
\text { value }\end{array}$} & \multicolumn{3}{|c|}{$\begin{array}{ll}\text { Parental influence } \\
\text { (GIRLS) }\end{array}$} & \multirow[b]{2}{*}{$\begin{array}{l}\text { 't'- } \\
\text { value }\end{array}$} \\
\hline & $\mathbf{N}$ & Mean & S.D & & $\mathbf{N}$ & Mean & S.D & \\
\hline $\begin{array}{l}\text { Group-A } \\
\text { Vs. } \\
\text { Group-B }\end{array}$ & 30 & $\begin{array}{l}61.23 \\
68.93 \\
\end{array}$ & $\begin{array}{l}9.86 \\
9.77 \\
\end{array}$ & $3.04 * *$ & $\begin{array}{l}30 \\
30\end{array}$ & $\begin{array}{l}64.43 \\
67.37 \\
\end{array}$ & $\begin{array}{l}9.11 \\
10.51\end{array}$ & $1.15 *$ \\
\hline
\end{tabular}

Score range: 20 to 100 ; ${ }^{*}$ Difference is insignificant, ${ }^{* *} \mathrm{p}<0.01$

High score indicates maximum parental influence on career choice and vice-versa. 
Career Choice Vis - A - Vis Personality Factors, Parental and Social Influence and Monthly Income of the Family - A Study

Table-5B: Comparison between the groups (considering monthly income of the family) in terms of social influence on career choice asengineer

\begin{tabular}{|c|c|c|c|c|c|c|c|c|}
\hline \multirow{2}{*}{$\begin{array}{l}\text { Comparison } \\
\text { between } \\
\text { monthly } \\
\text { income of the } \\
\text { family } \\
\text { (category - } \\
\text { wise) }\end{array}$} & \multicolumn{3}{|c|}{ Social influence (BOYS) } & \multirow[b]{2}{*}{$\begin{array}{l}\text { 't'- } \\
\text { value }\end{array}$} & \multicolumn{3}{|c|}{ Social influence (GIRLS) } & \multirow[b]{2}{*}{$\begin{array}{l}\text { 't'- } \\
\text { value }\end{array}$} \\
\hline & $\mathbf{N}$ & Mean & S.D & & $\mathbf{N}$ & Mean & S.D & \\
\hline $\begin{array}{l}\text { Group-A } \\
\text { Vs. } \\
\text { Group-B }\end{array}$ & $\begin{array}{l}30 \\
30\end{array}$ & $\begin{array}{l}56.27 \\
57.47\end{array}$ & $\begin{array}{l}11.78 \\
09.78\end{array}$ & $0.43 *$ & $\begin{array}{l}30 \\
30\end{array}$ & $\begin{array}{l}58.87 \\
59.53\end{array}$ & $\begin{array}{l}10.63 \\
08.94\end{array}$ & 0.26 * \\
\hline
\end{tabular}

Score range: 20 to 100; * Difference is insignificant.

High score indicates maximum social influence on career choice and vice-versa.

Droup-A: Rs. 20,001/- to Rs. 30,000/-

$>$ Group-B: Rs. 30,001/- to Rs. 40,000/-

\section{THE MAJOR FINDINGS OF THE STUDY ARE AS FOLLOW:}

- engineer: Overall findings reveal that those who want to choose their career as engineer are warm and outgoing, conscientious, trustful and self sufficient. On the other hand, those who are engaged in the professions as engineer are warm and outgoing, mature, conscientious, trustful, confident, self-sufficient and self-controlled. From the findings it can be said that personality factors of the students who want to choose their career as engineer is matched with the professionals although there seems to be indication of moderate levels of parental and social influences on career choice. Maximum parental influence is upon the boys who are in the category of comparatively high income level. It can further be said that the more the income level, the more is the parental influence on career choice. The reasons behind the parental influence in connection with the career choice are mainly due to - i) prestigious profession, ii) stability of the job, iii) future benefits and iv) to fulfill the expectation of the parents. On the other hand, social influence is more upon the girls who are in the category of comparatively low income level. The reasons behind the social influence in connection with the career choice are mainly due to- i) proper identity, ii) role models, iii) opinion of teachers and seniors and iv) the present scenario of the society.

- Parental influence is more upon the girls who want to choose their career as engineer.

- The more the income level the more is the parental influence - it is true for the students (boys) who want to choose their career as engineer.

\section{Applicative Potentials of the Present Study:}

Career choice is a vital factor in the present day scenario. The present investigation has highlighted the personality factors and the impact of parental influence on career choice as opined 


\section{Career Choice Vis - A - Vis Personality Factors, Parental and Social Influence and Monthly Income of the Family - A Study}

by the students who want to choose their career as engineer and Engineer. Considering the findings, of the study, the applicative potentials are as follows:

- Personality factors can be most powerful to know where one is and where one is going. So, there is a close relationship between personality factors and career choice. If the personality factors of the students are matched with their career choice, then, it is congenial and prosperous for their future development. In this investigation, the students who want to choose their career as engineer is matched with the professionals, so it is expected that they would be appropriate professionals in the near future. In this context, it can be said that for choosing a particular career, measures should be taken properly, considerably the concept"fitting the man to the job and job to the man".

- In this investigation, it was also found that there seems to be indication of parental influence on career choice. Undoubtedly, it can be said that the parents have an important role regarding career choice. But influence sometimes may create negative impact upon them and it is not appropriate for their future development. Care should be taken in this regard.

- Considering the social influence, it can be said that today's fast changing social scenario have an important role in connection with the career choice. Some significant factors like, social status, prestigious job, influence of peer group, financial benefit, advertisement etc. create impact upon the students in different ways. Proper information and knowledge about reality, social settings, and job availability, future benefit etc. should be informed them so that they may choose a particular career according to their own choice.

- Parents, teachers, counselors and other well-wishers may help the students to choose a particular career for their future if they know the personality, interest, aptitude etc. of the students properly. Adequate measures should be taken in this regard also.

- Proper guidance and counseling in connection with the career choice is required for becoming a good professional in the near future.

\section{REFERENCES}

Chaudhari, V.S., Vaidya S., Navalakha, N.G. and Mahapatra, B.C. (1998).Effect of teaching strategies and Socio economic Status on Self Concept of the learner. Indian Psy.Rew, 50(4), 216-223.

Das, D. and Das, A. (1981).Statistics in Biology and Psychology (Fourth Edition); Academic publishers, Calcutta.

Duffy, R. D., Borges, N. J., and Martung, P. J. (2009).Personality, Vocational Interests and Work Values of Medical Students. Journal of Career Assessment, 17, 189 - 200.

Gibson, R.L. and Mitchell, M.H. (2005).Introduction to Counseling and Guidance (Sixth Edition), Delhi : Pearson Education.

Hartung, P.J. and Taber, B.J. (2008).Career Construction and Subjective Well-Being.Journal of Career Assessment, 16(1), 75 - 85. 


\section{Career Choice Vis - A - Vis Personality Factors, Parental and Social Influence and Monthly Income of the Family - A Study}

Hojat, M., Glaser, K., Xu, G., Veloski, J. J. and Christian, E. B. (1999).Gender Comparison of Medical Students Psychological Profiles. Medical Education, 33 (5), 342-349

Keller, B.K. and Whiston, S.C. (2008).The role of Parental Influences on Young Adolescents' Career Development. Journal of Career Assessment, 16(2), 198 - 217.

Lease, S.M., and Dahlbeck, D.T. (2009). Parental Influences, Career Decision-Making Attributions and Self-Efficacy: Differences for Men and Women. Journal of Career Development, 36(2), 95 - 113.

Lievens, F., Coetsier, P., De- Fruyt, F., De MaeseneerJ. (2002). Medical Students Personality Characteristics and Academic Performance: A Five Factor Model Perspective. Medical Education, 36(11), 1050-1056

Otto, L.B. (2000).Youth Perspectives on Parental Career Influence. Journal of Career Development, 27(2), 111 - 118.

Perry, Justin C., Liu, Xiongyi and Pabian, Yvona (2010). School engagement as a mediator of academic performance among urban youth: The role of career preparation, parental career support and teacher support. The Counseling Psychologist, 38, 269 - 295.

Savickas, Mark L., Briddick, William C., and Watkins C. Edward (2002).The relation of Career Maturity to Personality Type and Social Adjustment. Journal of Career Assessment, 10(1), $24-41$.

Smith, H.M., and Betz, N.E. (2000).Development and Validation of a scale of perceived social self-efficacy. Journal of Career Assessment, 8(2), 283 - 301.

Telford, C.W. and Sawrey, J.M. (1964). Educational Psychology, $2^{\text {nd }}$ Edition, New Delhi, Prentice Hall of India (Private) Ltd.

Wang, N., Jome, La Rae M., Haase, R.F. and Bruch, M.A. (2006).The Role of Personality and Career Decision Making Self Efficacy in the Career Choice Commitment of College Students. Journal of Career Assessment, 14(3), 312 - 332.

\section{Websites:}

www.career.webindia123.com

www.careerchoice.com 